\title{
Renegotiating Locality and Morality in a Chinese Religious Diaspora: Wenzhou Christian Merchants in Paris, France
}

Nanlai Cao

\begin{abstract}
This paper explores the social and economic implications of indigenous Christian discourses and practices in the Wenzhou Chinese diaspora in Paris, France. Popularly known as China's Jerusalem, the coastal Chinese city of Wenzhou is home to thousands of selfstarted home-grown Protestant churches and a million Protestants. Drawing on multisited fieldwork, this study provides an ethnographic account of a group of Wenzhou merchants who have formed large Christian communities at home, along with migrant enclaves in Paris. The study shows how these migrant entrepreneurs and traders have brought their version of Christianity from China to France and how they perceive and deal with issues of illegality, moral contingency, native-place based loyalty and national belonging. It highlights the thoroughly intertwined relationship between an indigenised Chinese Christianity and the petty capitalist legacy of coastal southeast China in a secularised, exclusionary European context, and suggests that Christianity provides a form of non-market morality that serves to effectively legitimate Wenzhou's premodern household economy in the context of market modernity.
\end{abstract}

Keywords: religious transnationalism; moral discourse; Protestant Christianity; China and the Chinese Diaspora; Wenzhou economy; Paris

\section{Introduction: Mobility, Commercialism and Christianity in the Peripheral Context}

Research on immigrant Chinese Christianity has mainly focused on Chinese conversion to Christianity - the majority religion — in the Western context (e.g. Cao 2005; Yang 1999). Little scholarly attention has been paid to Chinese migrants who brought their Christian faith to the West from China and created their religious diaspora. This paper fills a gap in our knowledge on Christian transnationalism from the Global South by telling the story of a group of diasporic Chinese Christian (Protestant) merchants who hail from the southeast coastal city of Wenzhou and who are spreading Chinese commerce across the globe. It examines the business and religious lives of diasporic Wenzhou merchants at a time when 
China's likely role in the global market economy is compelling. The reform-era development of the Chinese economy can be characterised by the rise of private entrepreneurship, moral contingencies and aggressive global business outreach. In the last three decades Wenzhou merchants have prospered through production and trade, and their businesses have spread in China and across the globe. However, the cultural resources they have used to sustain their transnational business networks remain understudied.

This study focuses on a group of Wenzhou merchants who have formed large Christian communities at home, along with migrant enclaves in Paris. I address the question of how Wenzhou Christianity as a local indigenous form of Chinese Christianity can migrate to and become deeply embedded in a secularised European context, and show how these mobile economic agents reconstruct moral and native-place identities in diaspora through the idiom of global Christianity. By highlighting the dynamic diasporic construction of locality, this study seeks to contribute to recent anthropological efforts to 'recontextualise place in terms of longstanding and ongoing histories of mobility' (Taylor 2006, p. 249).

Migration and sojourning are central to the cultural identity of Wenzhou and to Wenzhou's reform-era economic success (Xiang 2005; Zhang 2001). As perhaps the most globally visible Chinese merchant group today, Wenzhou people have been dubbed as 'China's global go-getters' (Lee 2007). Within China their mobility and commercialism have given them the name 'Jews of China'. Historically, migration and religious involvement have been closely intertwined with Wenzhou people's daily commercial practices. This has to do with what Hill Gates' (1996) calls a weak state tributary mode of production and strong petty capitalist mode of production that can be traced back to a millennium ago when a coastal economy focused on ship building and commercial transportation took shape on the southeast coast of China. In contrast to an agriculture-based economy that dominates in most parts of China, the longstanding history of petty capitalist commodity production in coastal Wenzhou has produced a distinctive regional culture of commercialism. In the post-Mao era, Wenzhou people have mainly engaged in a household-based market economy, producing and exporting low-end small merchandise such as shoes, cloths and cigarette lighters. As a denselypopulated coastal port city, Wenzhou's historical trading links with the outside world facilitated the introduction of Christianity from the West. The active presence of the Western missions in the first half of the 20th century and the contemporary development of an indigenised Christianity in Wenzhou both benefited from Wenzhou's peripheral location. Today, Wenzhou is home to as many as one million Protestant Christians and two thousand churches, and Christianity has become the fastest growing religion in local society. 
Transnational connections and imaginations enable the Wenzhou church to achieve a competitive edge in the post-Mao domestic religious market. In some sense, Wenzhou Christianity is inherently transnational and embodies the fusing of the local and the global in a novel form. The case of Wenzhou Christians in Paris allows us to examine the ways nonWestern Christians negotiate their local place-based distinctiveness in relation to a modern Western culture with which they have come into intimate contact in a globalized milieu.

Adopting a multi-sited ethnographic approach to the religious and business practices of these Wenzhou migrant Christians, I made four separate field trips to Paris and numerous short trips to Wenzhou during 2010-12. ${ }^{1}$ With the help of my Paris-based research assistant, I was able to gain good access to these Chinese migrants' churches, homes and shops. We did around twenty life history interviews, each of which took 2-3 hours. These vivid life stories, along with findings from participant observation in various church settings, help piece together a relatively coherent picture of how Wenzhou Christianity takes root in Paris.

\section{Peasant Subjects and the Making of a Chinese Religious Diaspora}

For Wenzhou Christians, the notion of the Wenzhou church extends beyond Christian sites in Wenzhou to other countries, especially European ones. Many migrant Wenzhou churchgoers in Paris come from the same parishes in their hometown. When referring to the Wenzhou church, these migrant Wenzhou believers have to pay attention to distinguish between 'the Wenzhou church here' in Paris and the Wenzhou church in China. In some sense, the Wenzhou migrant church community in Paris can be considered as an excrescence from the Wenzhou entrepreneurial model of Christian revival in China (see Cao 2011).

Estimates put the number of Wenzhou migrants in Paris at around $100,000 .^{2}$ There are more than a dozen costly Wenzhou Chinese migrant churches in Paris. Though a small number of Wenzhou pastors have been invited to minister the migrant churches there, few Wenzhou Chinese have migrated to Western Europe for purely religious reasons and most engage in retail and wholesale trade with a dream to get rich. The largest group within the Wenzhou migrant community in Paris today came from a rural county called Li'ao in Wenzhou. In the mid 80s, a 'Wenzhou village' was formed as more and more Wenzhou people migrated from Li'ao to Paris and settled in Arrondissements 10, 11, 19 and 20. One Wenzhou preacher describes this transnational population movement as the 'transportation of a whole county from Wenzhou to France'. Few Parisian Wenzhou migrants are from the three main urban districts of Wenzhou City (Lucheng, Ouhai and Longwan). 
In the Parisian Wenzhou society Christianity appears as both a universal cultural representational form and a diasporic reality. The religion plays a part in the social life of Wenzhou merchants in Paris by shaping how believers perceive and deal with issues of illegality, moral contingency, native-place based loyalty and national belonging. These migrant Wenzhou Christians have adopted a religious meaning frame to ground their business practices in an alien social space.

What distinguishes the migrant Wenzhou churches from Western or other overseas Chinese Christian communities is their insistence on maintaining the principle of institutional autonomy and close transnational ties to the church communities back in Wenzhou. This resembles the business dealings of Wenzhou migrant enclaves in Europe (Wang and Béja 1999). For example, these migrant Wenzhou churches regularly invite Wenzhou preachers to preach in Europe in Wenzhou dialect, and pay their travel expenses. The Parisian Wenzhou church (bali Wenzhou jiaohui), the largest migrant Wenzhou church in Paris with more than 1,000 baptised members, has contributed 30,000 euros to the establishment of a seminary in rural Wenzhou and continues to provide funding to cover the costs of student recruitment and seminary studies. The migrant church has also set a rule that they will immediately contribute 1,500 euros to any single church building projects in Wenzhou whenever they receive a fundraising request. Major migrant Wenzhou church groups in Paris have either already purchased or planned to purchase their own gathering places. Some migrant church leaders understand their strong desire to buy church property in terms of a Chinese cultural emphasis on face or mianzi. Owning the church property for ordinary Wenzhou churchgoers is like having a home in Paris in both a material and spiritual sense. Expansion of translocal Wenzhou church space accrues enormous moral prestige to Wenzhou Christians worldwide.

The proportion of Christians among the total Wenzhou migrant population in Paris remains unknown. I estimate that around 10-20 per cent of Parisian Wenzhou Chinese would be Christians, which is more or less consistent with the Christian proportion back in Wenzhou. Christian faith has almost no impact on their decision to become immigrants, whether legal or illegal. In fact, experiences of migration and displacement can often foster or strengthen one's religious commitment. I was told that a few undocumented Wenzhou migrants converted to Christianity to seek or thank God's divine protection on the treacherous journey to Europe which might take several months and span many countries in northeast and southeast Asia and continental Europe.

There is also no necessary correlation between Christian faith and moral behaviour among Wenzhou migrants in Paris. Both Christian and non-Christian Wenzhou migrant 
businesses routinely engage in tax evasion and hiring illegal migrants. In the Parisian Wenzhou community Christian-run businesses apparently have greater concern with ethical and moral conflicts, but this does not mean that their ethical conflicts have been dealt with effectively. When asked to compare Wenzhou Christians and non-Christian Wenzhou migrants in their social and business practices, Brother Chen, the president of the Parisian Wenzhou church said, after pausing for a few seconds, 'Christians are only more hardworking than non-Christians here as we Christians have to both go to work and go to church'. For Parisian Wenzhou Christians, native place identity and family business needs appear to take priority over the ethical commitment that one would assume is associated with Christian faith. Within the church circle, wealthy families do not want to disclose their wealth for fear that others would report their illegal business practices to the authorities out of jealousy. For the same reason, it is also a taboo to openly discuss personal and family economic matters in the church. One middle-aged Wenzhou church sister and small shop owner said that it took her three years to find out who are really rich in her church.

Migration is a selective process and this is especially so when it comes to undocumented migration primarily driven by economic motivation. The majority of the Wenzhou people in Paris are middle-aged, first-generation migrants who arrived in France in the 1980s and 1990s, often with a strong desire to accumulate initial capital and set up their own family businesses. Most of them paid snakeheads a smuggling fee of about US\$20,00030,000 to come to Paris. This also applies to the Christians who in their migration narratives often emphasise the 'human instinct of seeking upward mobility' (renwang gaochu zou) and downplay the illegality of human smuggling. For some, the hardships and suffering they have experienced on their way to Paris have strengthened their faith and become testimonies of their dependence on and search for God. In the eyes of many emigration benefits families in the sending society by liberating young people's entrepreneurial spirit and thus should be encouraged as much as possible. Not surprisingly, some migrant Wenzhou church leaders have expressed shock about the laid-back French life style such as low marriage rate, high female smoking rate, young people's consumerist desire, and most importantly their having no aspiration to be a 'boss' (laoban).

For most Wenzhou migrant Christians, their life is centered on two things, making money and serving the migrant church. This self-isolation is common among the Wenzhou migrant community, especially among the first generation. The migrant church circle is their only extended social network in Paris beyond their families. Having lived in Paris for 18 years, Brother Chen knows no French and claims to have no time to read Chinese newspapers 
or watch Chinese TV programs. When asked if he likes French food, he said he only likes McDonald's - a distinctive French food in his eyes. He usually eats McDonald's after he comes back from conducting visitation for his church. It is thus not difficult to understand why competition for leadership positions in the migrant church has been so fierce among some middle-aged and elderly men. There have been quarrels and even physical conflicts in front of the whole congregation, to which I was eyewitness. ${ }^{3}$ While most church members deplore the disunity of the church, they greatly enjoy commenting on this 'drama' of power struggle unfolding before them. For those active male lay leaders, they seem to desperately need a religious form of compensation for their lack of control over their lives in the new society. The reassertion of traditional patriarchal authority also features prominently in the Christian diaspora of Korean Americans (Min 1992). Neither migrant folk networks nor professional associations can accommodate mass participation as effectively as congregationbased evangelical Christianity does with a large, openly participatory domain. For linguistically and culturally handicapped men from rural coastal China, the migrant church is most likely their only chance to participate in communal politics in Paris.

\section{Marriage and Family Life in Diaspora}

Although the massive migration from Wenzhou to Paris is essentially an entrepreneurial migration, religion is an integral part of how economically ambitious Wenzhou Christians construct their lives and identities in diaspora. Parisian Wenzhou migrants often tell me that the main difference between Wenzhou migrants and other migrant groups from China is that Wenzhou people come to stay, attain residency papers, bear children and do business while other Chinese groups only come to work for one or two years to make quick money before returning to China. Wenzhou migrants have knowingly embarked on this one-way journey with no intention to return permanently to their place of origin. As the migrant family is the basic unit of petty capitalist production for Wenzhou people, it is perhaps no coincidence that sermons preached at the migrant churches have placed heavy emphasis on marriage and family stability, which is viewed as the foundation of any major entrepreneurial initiative. Divorce is extremely discouraged. One middle-aged Wenzhou church leader and textile businessman bragged about his church's zero divorce rate and shared an intriguing story of how he successfully persuaded a Wenzhou couple in the church to stay married after both were suspected of having extramarital affairs. This conservatism has to do with the fact that both the domestic space and the church space of the Parisian Wenzhou migrants are inscribed 
with a patriarchal morality. The Bible verses that are often read aloud by the preacher and the congregation during weddings held at the migrant Wenzhou churches are Genesis 2:18-24 and Ephesians 5: 22-30, emphasising that wives should submit to their husbands because God created man before woman.

Both in public and private conversations Wenzhou preachers and ordinary church members have attacked French society (including French Christians) for its lax sexual morals as seen in their tolerance toward divorce, abortion, homosexuality and excessive personal freedom. The conservative evangelical orientation can also be found among Chinese Christian churches in the United States, helping preserve desired Chinese cultural traits among the second generation Chinese Americans (Cao 2005; Yang 1999). But unlike Chinese American Christians who generally hold positive attitudes toward assimilation, Parisian Wenzhou Christians embed themselves in a religious diaspora and in a unique transnational Chinese space (cf. Nyíri 2003).

The migrant Wenzhou churches recruit preachers and members not only from existing networks in Europe but through secular arrangements that enable them to circumvent restrictive immigration control so as to link up with the Wenzhou church system back in China. Some preachers have travelled to Europe from Wenzhou on non-immigrant visas sponsored by migrant Wenzhou Christians or their enterprises. Some single young church sisters who had achieved legal residency returned to Wenzhou to marry a Christian man and then brought him back to Paris. In the diasporic Wenzhou church circle, devout young female believers are especially encouraged to marry male preachers in Wenzhou so as to bring them to Paris to serve the migrant Wenzhou church community and provide daily pastoral care in authentically Wenzhou style. This practice is viewed positively as church sisters 'sacrifice' in the Wenzhou church. The young male fulltime preachers, often economically marginalised, unsurprisingly attribute their 'marrying up' the socioeconomic ladder to 'God's grace'. Moreover, they become the envy of other fulltime preachers, not only because this is a divine blessing but also because they have avoided the physical and psychological costs associated with (usually undocumented) international migration. Some Wenzhou church workers did enter France illegally, in their words, in order to 'make euros'. It is not unheard of for preachers to have been smuggled from Wenzhou into Europe to serve migrant Wenzhou churches. Recruiting clergy for the migrant church through transnational marriage has become an important feature of the Wenzhou-centred transnational evangelisation movement, according to a Wenzhou preacher who draws parallels between the Wenzhou model of economic development and what he calls 'the Wenzhou model of evangelisation'. Although 
clergy of the Parisian Wenzhou church community are not active in reaching out to nonChristian Chinese migrants in France due to their emphasis on the uniqueness of Wenzhou culture and the distinction between Wenzhou migrants and other Chinese migrant groups, many have joined church groups back in Wenzhou in conducting evangelisation in China's impoverished rural hinterland. By stressing a Wenzhou model in church development and the elite status of Wenzhou in the global Christian movement, Parisian Wenzhou churches contribute to the formation of a distinctively Wenzhou-centred Chinese Christian diaspora.

However, from this Wenzhou model of evangelisation one can actually get a sense of Wenzhou migrants' reluctance to marry Chinese from other places and ultimately their insistence on maintaining the premodern petty capitalist mode of production. The preference for a Wenzhounese mate is intense among my informants and is very explicitly expressed. In one case, a young Wenzhou man (a preacher's son) who came to Paris on a short-term tourist visa was introduced via the migrant church to a Wenzhou woman who came to France at the age of nine and had achieved citizenship. They got married three months after they first met in Paris and right before the young man's tourist visa expired. Two months after their marriage the young couple started making leather bags for the wife's family business. The woman who is also a Christian said in retrospect that she trusted him and believed he was the right person for her at first sight because 'a preacher's son must be trustworthy'. They just met a few times on weekends before they got married. For the most part immigrant Wenzhou churches provide a highly controlled setting in which the younger generation of Wenzhou immigrants can interact and meet their potential mates. Marriage outside of the Wenzhou immigrant community is strongly discouraged, because it would 'dilute' the much cherished Wenzhou model of family business. A Parisian Wenzhou Christian would be the most preferred marriage candidate partially because Christian faith testifies one's righteousness and suitability as a mate especially in the perceived French context of lax sexual morals. More important, religious networks and connections bind Wenzhou immigrants closer to one another and reinforce a traditional Chinese family model both metaphorically and materially. One young preacher originally from Li'ao said, 'If you don't have relatives in the church now, sooner or later you will have'. This implies that if you are single you may eventually get married with someone in the migrant Wenzhou church, and if you are already married you will have your sons or daughters married with others in the church circle. The perceived lax morals of French society may have furthered the migrant church's fundamentalist tendency and cultural conservatism. 
At this contemporary global moment, Christianity also provides these migrant traders and their relatives a secure social space for the production and reproduction of a multisensorial experience associated with their native place and their imagination of an extended Wenzhou family (see Chau 2008). In the migrant church setting, people listen to sermons and discuss church affairs in local dialect and at special gatherings share their food items just brought back from trips to their hometown Wenzhou. A famous Wenzhou local snack is the processed and prepacked duck tongue. In Wenzhou people usually have duck tongues as an appetiser or a side dish for drinking. In Paris I was invited a few times to a Wenzhou Christian couple's home for dinner with more than a dozen Wenzhou migrants attending the same church on Sunday nights. In this regular weekly gathering, the couple prepared all the dishes in local Wenzhou style except the after-meal dessert (French style salad) and the premeal espresso that they drink together with the duck tongue snack. Over an authentic Wenzhou meal people debated in Wenzhou dialect what they personally believed to be the right path for church development. For first-generation migrants, the migrant church enables them to participate in public life and decision making in Paris without becoming French or ethnic Chinese. By combining Wenzhou's unique regional culture with global Christianity, Wenzhou people can assert their local pride in the context of China's global business expansion. One Wenzhou Christian once commented on Wenzhou Christianity's global reach in comparative terms, 'Wherever Wenzhou people travel they would maintain their life style and their worship style. But outsiders (referring to other Chinese groups) often become a plate of dispersed sands (yipan sansha); they seek to integrate into the host society but if they fail they would usually feel inferiour'.

It remains to be seen how the younger generation would like to lead a life and negotiate their self identity, being embedded in a simultaneously transnational and closed ethnic network that their parents' generation has constructed. When I asked the president of the Parisian Wenzhou church what would happen to the church when the younger generation of French-born members come of age, and if the Wenzhou migrant church would become a French church one day: 'This will never happen'. To my surprise, he replied with a sense of self-righteous pride. Indeed, many parents in the church try to keep their children culturally Chinese with the hope that one day they can do business in China. Many send their children to Sunday Chinese language schools to learn Mandarin because of the perceived rise of China as a global economic power and because Mandarin has become an international business language (cf. Nagata 2005). Some well-to-do families send children back to Wenzhou to learn Mandarin. Many youths speak fluent French, and they often talk to their parents in 
French mingled with Wenzhou dialect and Mandarin Chinese. In larger migrant Wenzhou churches, there is a worship service for these French-speaking youths each Sunday. Although they sing hymns in French, the sermon is often given in Mandarin Chinese by a first generation migrant preacher with the help of a Mandarin-French interpreter. The preacher also makes the beginning and concluding prayer in Mandarin. The values of the French-born church youths are heavily influenced and controlled by the first-generation immigrants. Moreover, Parisian Wenzhou church leaders have insisted on the necessity of 'training' (peiyang) the younger generation in a distinctively Wenzhou Christian way so that they will not mingle with the French mainstream which is perceived as a cultural threat (also a religious threat, to a lesser extent) — the 'authentic faith' can be passed on.

\section{Becoming Superior Locals, Overcoming Illegality and Marginality}

Parisian Wenzhou Christians have consciously redefined the boundaries of belonging among different Chinese migrant groups in the moral and ritual contexts of the church. By drawing distinctions from other Chinese migrant groups and non-immigrant Chinese students, Wenzhou migrants gain a privileged sense of being local. Accordingly, they seldom talk about Wenzhou as their home or hometown as Wenzhou has become a transnational economic and cultural form embedded in their diasporic consciousness. For those who have yet to achieve citizenship or legal status in France, the migrant church provides an alternative public sphere in which they can voice their immediate concerns in a religiously sanctioned way (see Kipnis 2004).

There are almost no university students from other parts of China involved in migrant Wenzhou churches. This has to do with the serious mutual stereotyping between Wenzhou migrants and non-immigrant Chinese students in France. The former say the latter only have dreams but no practical skills, while the latter speak of the former as uncouth new-rich obsessed with making money. The result is that when non-immigrant Chinese students come to attend services in Wenzhou migrants-dominated churches, they are routinely directed to Chinese student fellowships in Paris (see Hua 2009). The 'failure' to retain non-Wenzhou Chinese members is often attributed to the Wenzhou congregants' desire for more specialised and culturally sensitive pastoral service.

The use of the term 'outsider' (waidiren) to address Chinese people from other places (usually less developed than Wenzhou), and the separate parallel programs and services for Wenzhou people and non-Wenzhou Chinese in Parisian Wenzhou churches, are no different 
from what I observed among the Wenzhou churches in China. In Wenzhou, many believers take Christianity as a symbol of Western modernity. But to these Wenzhou migrant believers in Paris what is Christian modern is actually local Wenzhounese, while what is local Parisian is ironically foreign. Arguably, this is less a case of localisation of global Christianity than a story of active participation of uprooted rural migrants in a form of Christian cosmopolitanism to seek cultural empowerment and local embeddedness.

For many Wenzhou migrants in Paris, their rural origin is a stigma that they constantly hope to shed. In many ways, they might resemble rural migrant workers in China who are driven to the city by their longing for modernity and material success. One bettereducated elderly Wenzhou Christian once spoke of fellow Wenzhou people in Paris in a slightly self-derisive tone, 'they look like people who insist on wearing western suits but don't bother with taking a bath or shower'. This caustic remark may apply generally to rural Wenzhou people with unfulfilled cosmopolitan desires. However, textually-based Christianity not only provides these culturally handicapped migrants access to a knowledge of the sacred but also enables them to produce knowledge about the new world in which they are a cultural Other. Moreover, Christianity furnishes both autonomous ritual space and a repertoire of cultural metaphors that allow new Chinese migrants to position themselves as 'morally superiour' locals and facilitate their self-development in the hostile new land where immigrant entrepreneurs face legal discrimination (see Dinh and Ma Mung 2008).

Nearly all Wenzhou Chinese migration to Paris is illegal. It is hard and even unethical to ask them to recall their always painful experiences of undocumented transnational migration and to discuss their often unlawful business practices in Paris. While I have sympathy with those who bend the rules to seek a better life for themselves and their families, I have also sought to stay detached when analysing the controversial image and life of these Wenzhou migrants. By attending to how they mobilised resources and networks available to them to achieve legitimacy for their illicit activities, I give due respect to my informants' struggles for a normalised path toward social mobility in France.

Clergy of the migrant Wenzhou churches have developed a 'theology of the undocumented' (Freston 2008) for understanding the issue of illegal migration in the deeply moralistic context of evangelical Christianity. Brother Chen, a 58-year old Christian merchant and the president of the Parisian Wenzhou church was one of the few people who liked to share with me how Wenzhou migrants deal with moral contingency associated with illegal migration. Like most Wenzhou Chinese in Paris who follow a family-based migration pattern, Brother Chen came to Paris with his wife and two children in the early 1990s all as 
undocumented immigrants. Now all his family members have achieved legal residency in France. He kindly treated me pizza and beer in his pub, which he bought last year for 900,000 euros. Without French skills, he hired a dozen young French waiters and waitresses. Apparently, his bilingual son has been a great help in running the pub. When asked to comment on his migration practice in relation to his Christian faith, he replied by referring to the biblical figure Abraham (in the Book of Genesis) who travelled to the land of Canaan (modern day Israel), apparently without a visa. 'In God's kingdom, the whole world is a family. Nations have their laws, but in the Bible there is no such thing [immigration control],' he said assertively. At the moment I could sense his disdain for the nation-state based 'legal production of migrant illegality' (De Genova 2004). In a more theological-sounding language, the Parisian Wenzhou church's pastor and a businessman Brother Zhou asked me to note the fundamental difference between committing a 'sin' (fanzui) and making a 'transgression' (weifa) when looking at the issue of illegal migration. He himself was an illegal immigrant and first arrived in Paris after a journey spanning several countries and over fifty days. It was God's grace that he survived the journey, according to him. He made it clear that illegal migration is a transgression, a violation of the rule set by people, but not a sin committed against God. So, in his words, Christians should take it easy as their sins are already forgiven in Christ. Clearly, the fundamentalist language provides justification for the technically illegal practice, in this case. And by practicing modern Protestant language ideology the speaker not only emancipates him/herself from the material and institutional context of stateproduced illegality, but also significantly widens the gray areas in a meaningful way (cf. Harding 2000; Robbins 2001).

As highlighted by Julie Chu's (2010) ethnography of rural Fuzhounese desires for transnational mobility, migrants from China's rural coastal regions to the West often see legality as a resource to be achieved rather than naturalised entitlement under state regulations. This constructed nature of migrant legality can be fruitfully compared with the Parisian Wenzhou church's emphasis on the gradual development and growth of individual spirituality. In the migrant church community, legal residency or citizenship has become an ‘independent axis' of social difference and inequality (Kipnis 2004). Illegal migration used to be a hotly debated issue in the church in the 1980s and 1990s as the new arrivals found it difficult to reconcile Christian faith with illegality. A middle-aged churchgoer complained that no matter how much church work he volunteered to do in his first few years in Paris, as an illegal resident he received much criticism from those who had achieved legal status. But today with most churchgoers having achieved legal residency, there is almost no mention of 
the issue in the church circle any more. While people do not openly discuss the issue of legal residency, where you come from as well as your residency status always matters especially if one wants to serve the migrant church. In the Parisian Wenzhou church community major church leaders are all middle-aged or elderly Wenzhou businessmen who have spent decades in France and achieved French citizenship.

Apart from undocumented migration, tax evasion is another illegal but routine practice among the Wenzhou migrant merchants, including both Christians and nonChristians. A Wenzhou migrant church's elder used the word 'too conservative' to describe the payment methods of his French business partners who usually prefer sending and receiving payment via bank transfer. Pastor Zhou told me he cannot preach on business ethics in the migrant church at the moment although he was well trained in Christian ethics back in his seminary. This is because he himself is still doing business. By implication, he admits he is one of the moralising, tax-evading Chinese Christian merchants in Paris. Reluctant to reveal any details about his business practices, the pastor was much into sharing with me his extensive experience conducting evangelical and theological education in China. He shared with great joy how he fulfilled his dream of getting his seminary education in Malaysia and of being able to establish an underground seminary in Wenzhou with the support of local Christian entrepreneurs and the tacit consent of local Religious Affairs Bureau officials. In the process of conducting this multi-sited ethnography, I followed him to China after we met in Paris. I attended a series of theology courses he offered during the summer in Wenzhou; he used a very conservative language associated with moral absolutism to train those local Chinese church workers and preachers especially when it came to such issues as premarital sex, homosexuality and abortion. But when it comes to worldly business engagement, he always resorts to the so-called contextual theology to make sense of the imperfect institutional environment in which all the unlawful practices take place. For him, the illegality of Wenzhounese migration and business practices can be compared to the illegality of the 'glorified' underground house church movement in China and thus theologically justified. $^{4}$

Nevertheless, the Parisian Wenzhou migrants' Christian moral identity exacerbates their sense of anxiety associated with illegality, which makes them unwilling to share life stories especially when they meet with the researcher for the first time. One day Brother Zhou introduced me to a deacon in the Parisian Wenzhou church who is said to be the biggest and most successful merchant in this church. Having lived in France for three decades, he initially agreed to be interviewed but rejected my request after knowing I was going to 'collect some 
testimonies' on the relationship between his business operations and Christian faith. When I tried to chat with him on his transnational garment business after a Sunday service, asking him if his international garment business has a higher profit margin than local restaurant industry, he said in an impatient tone, 'you should ask those who run restaurants here. Don't ask me. I know nothing about it'. My attempt to start a conversion with him failed. Later during the lunch break, he came to shake hands with me and apologise for not being able to help with my research. He said that his comment on his success story is, in a word, 'all God's grace'. The emphasis on the divine power and downplaying of individual human agency may sound familiar to those experiencing moral difficulties elsewhere. The day before my departure I had a causal chat with the Brother Zhou over a cup of espresso. The pastor is close to this successful garment businessman who declined my interview request. I asked him why people don't like to share their testimonies about business success. He didn't answer me directly but suggested that I should not ask any questions about 'Christian business'. Apparently, Christianity and business are grounded on divergent moral assumptions and belong to two separate domains of action in the Wenzhou diaspora. Writing on moral discourse in rural southeast China, Ellen Oxfeld (2010) has pointed out that the morality of an action is often tied to the domain in which it occurs, although boundaries of different domains can be quite blurred in the local world.

I gradually come to realise that tax evasion and undocumented migration are the two most sensitive almost-unspeakable issues continually haunting the morally contingent Wenzhou migrant community in Paris. Often closely associated with tax evasion, hiring illegal immigrants is another routine practice among migrant Wenzhou businesses striving to maximise profits. Some church leaders have recruited their undocumented relatives and church members in their family-run workshops. Although in Christian terms these people can be seen as sinners as one time undocumented immigrants and cunning tax dodgers, Christianity as a form of universal culture lends a powerful meaning framework for enterprising and morally ambivalent Chinese merchants to flexibly engage global capitalism. The notion of God's grace is frequently invoked to provide legitimacy for their theoretically illegal migration and business practices, and it also represents an effort to theologise their day-to-day life in an alien social environment. By appealing to the highest (divine) sovereignty, these Chinese traders and merchants have created a transnational transcendent world in which they are not undocumented migrants but God's children with full social entitlements. Their justified sinlessness transforms them into glorious citizens of God's kingdom. This ideal of universal Christian citizenship defies the assumption that human 
dignity and equality can only be recognised, pursued and found in a nation-state framework rather than across national borders (see Kipnis 2004; Levitt 2007).

Unlike the case of New York City's Chinatown (Zhou 1992), institutionally the migrant Wenzhou Chinese community in Paris does not operate in the form of an ethnic enclave economy embedded in the nation-state framework. Many Chinese merchants in Paris engage in family businesses specialising in manufacturing and trading garments and garment accessories on a worldwide scale. The immigrant community serves as a hub for the global circulation of information, capital, labour and materials for Wenzhou merchants in diverse places (cf. Xiang 2005). As many import leather goods and garment materials directly from China, their transnational economic practices help expand China's export market in Europe (Ma Mung 1998). In contrast to American Chinatown residents who seek to first embrace and then deflect from ethnic religious networks in order to achieve upward mobility through 'segmented assimilation' (Cao 2005), this generation of Wenzhou Chinese migrants embrace religion not as a conscious temporary strategy for survival in a strange place but as an embodiment of their permanent emotional attachment to their native place and expression of loyalty to informal communal networks under the context of globalisation. While Chinese Christians in the United States are mostly new converts (Yang 1999), these Wenzhou Christians are proud of their family faith tradition and like to frame the city of Wenzhou as 'China's Jerusalem', the largest urban Christian center in China (Cao 2011). Like many selfstarted home-grown churches in Wenzhou, Parisian Wenzhou churches rely heavily on the financial contribution of mobile Wenzhou merchants. The largest Wenzhou migrant church in Paris receives tens of thousands euros from its congregants weekly. Wealthy congregants and lay leaders feel obliged to make generous donations to the church. The idea of pooling money together to fund a group investment project is familiar to Wenzhou people, both Christians and non-Christians. Although the church, due to its firm claim to transcendence, does not function as a credit association for the Wenzhou migrants, the concept of pooling, itself widely accepted in the church circle, helps many members of the diaspora overcome a sense of marginalisation. When the symbolic boundaries of the migrant Wenzhou churches overlap with those of the Wenzhou trade diaspora, especially at the moment of Wenzhou merchants pooling funds to invest in new church space, these mobile Christian merchants are able to achieve maximum certainty, security and sense of intra-group bonding in a rapidly changing environment.

\section{Conclusion}


As Pál Nyíri (2003) has suggested, transnational Chinese evangelical ties can be easily tied in with transnational Chinese business networks especially in promoting the discourse of global Chineseness and patriotic citizenship. My ethnographic analysis goes further and shows that global Christianity has become a symbolic carrier of worldwide Chinese economic movements and an important element in the diasporic construction of an indigenous Chinese capitalist locality in the context of intensified reform-era globalisation of China. The communal-based organisation of diasporic Wenzhou Christianity and the large community of morally contingent Christian merchants in Paris counter the Western Enlightenment model of civil society that is firmly embedded in national space. The Wenzhou Christian diaspora also contrasts sharply with Taiwan-centred global Buddhist Tzu Chi diaspora in which personal charismatic leadership, rather than salient indigenous cultural markers, plays a powerful determining role in making transnational connections and global outreach efforts (Huang 2009). Christianity provides a moral discourse for Wenzhou migrant merchants and traders to ground their native place networks and distinctive family businesses in a place where they are stigmatised by the secular state practice of immigration control and management.

Paradoxically, it is a conservative moral discourse that confers legitimacy to their morally ambivalent petty capitalist practices. This non-market morality serves to legitimate Wenzhou's premodern household economy in the context of market modernity. At the same time, these mobile Christian merchants deploy native-place-based networks to expand the spatial scope of Christianity. Their practices and experiences illustrate the mutually constitutive processes of local place making and a global religious resurgence.

The mobility and commercialism of Wenzhou people challenges the state production of illegality. The migrant Wenzhou churches emphasise and celebrate such essentialised Wenzhou cultural traits not without self-reflection. Referring to the passages in Exodus in the Bible, a middle-aged migrant Wenzhou preacher and garment factory boss made the following remarks in a Sunday sermon:

God chose prosperity for Israelites in Canaan. If God had chosen Wenzhou people, can we imagine what we would have done? I think we Wenzhou people are even smarter than Jews. Wenzhou is often called China's Jerusalem, and Wenzhounese are the Jews of China. If we were the chosen people, we would have stayed in Egypt, slaughtering cattle and sheep and making leather hand bags and garments. We would never think about going to Canaan. Therefore, God has his arrangements. We cannot understand him according to our own reasoning. 
This embarrassing self-awareness produces a form of 'cultural intimacy' (Herzfeld 2007) that is vital to the construction of a defensive counter-stereotype among the morally ambivalent Wenzhou merchants. Claiming Wenzhou's cultural essence, these Christian leaders generally hold explicit anti-assimilative attitudes and actively maintain the boundaries of an intimate religious space for Wenzhou migrants. By drawing metaphorical parallels between Canaan and Paris, between Jews and Wenzhou people, they sanctify Wenzhou people's peripheral movements in both the Chinese and French contexts and naturalise a strong economic imperative in diaspora. The thoroughly intertwined relationship between an indigenised Chinese Christianity and the petty capitalist legacy of coastal southeast China, as it continues to play out in this secularised European context, is not a manifestation of the Protestantcapitalist nexus identified by Max Weber, but is profoundly informed by the cultural logic of a ritual economy in which rural Wenzhou's rapid economic development is embedded (Yang 2000). By stressing elite responsibility for ritual expenditure and the display of public generosity, this ritual economy has channelled migrant entrepreneurs' newfound wealth from transnational business to the expansion of a diasporic religious community.

Despite some church leaders's wishful thinking that their churches will always remain Chinese and especially Wenzhounese, this indigenous form of Christianity can hardly be passed on to the younger generation of mostly French-speaking Wenzhou Chinese when they come of age and have economic and cultural options in the mainstream society. ${ }^{5}$ For the time being, Christianity provides a normative and morally superior context for imagining their native place and a shared future of their cultural positioning in increasingly exclusionary France. It enables these transnational Chinese subjects to transform themselves from passive receivers of the mainstream Western culture to active producers of cultural knowledge about their lived diasporic realties. That this indigenous Chinese Christianity can travel well from Wenzhou to Paris is mainly due to its sticking to a language of absolutism and its emphasis on the acquisition of autonomous ritual space, allowing these seemingly rootless migrants to very effectively renegotiate a sense of belonging and moral selfhood in a transnational, peripheral context.

\section{Notes}

${ }^{1}$ I acknowledge the funding support of this research by a General Research Fund grant from Hong Kong Research Grants Council (Project code: 740509) and research assistance provided by Xiao Yingying, a doctoral student at the University of Paris VII. 
${ }^{2}$ For a detailed account of the formation of the Wenzhou migrant community in Paris, see Wang and Béja (1999).

${ }^{3}$ On 1 May 2011, dozens of French police officers raided the Parisian Wenzhou church after receiving reports that fights had broken out among the congregation over who should preside at the Holy Communion. The police made several arrests including the president Brother Chen who was later charged with assault.

${ }^{4}$ In Wenzhou, Christian businessmen deal with illegality in a similar way. Some may bribe local officials but take it as an act of 'robbery by the officials' rather than their intentional act of wrongdoing, and they would pray for God's mercy afterwards. Some evade tax and give an excuse that they would donate more money to the church in future.

${ }^{5}$ Resembling the development of second-generation Asian American English language ministries (see, e.g., Chai 1998), several French-speaking Parisian Wenzhou youth fellowships have split or are intending to split from migrant Wenzhou churches to become independent due to their unique cultural experiences,

\section{References}

Cao, N. (2005) 'The Church as a Surrogate Family for Working Class Immigrant Chinese Youth: An Ethnography of Segmented Assimilation', Sociology of Religion, vol. 66, no. 2, pp. 183-200.

Cao, N. (2011) Constructing China's Jerusalem: Christians, Power, and Place in Contemporary Wenzhou, Stanford University Press, Stanford.

Chai, K. (1998) 'Competing for the Second-generation: English-language Ministry at a Korean Protestant Church'. in Gatherings in Diaspora: Religious Communities and the New Immigration, eds R. S. Warner \& J. G. Wittner, Temple University Press, Philadelphia, pp. 295-332.

Chau, A. Y. (2008) 'The Sensorial Production of the Social', Ethnos, vol. 73, no. 4, pp. 485 504.

Chu, J. Y. (2010) Cosmologies of Credit: Transnational Mobility and the Politics of Destination in China, Duke University Press, Durham.

De Genova, N. (2004). 'The Legal Production of Mexican/Migrant 'Illegality', Latino Studies, vol. 2, pp. 160-185.

Dinh,B. \& Ma Mung, E. (2008) 'French Migratory Policy and Immigrant Entrepreneurship', in Migrações Journal - Special Issue on Immigrant Entrepreneurship (eds C. R. Oliveira, \& J. Rath), no. 3, ACIDI, Lisbon, pp. 85-97. 
Freston, P. (2008) 'The Religious Field among Brazilians in the United States', in Becoming Brazuca: Brazilian Immigration to the United States, eds Braga, L.J. \& C. Jouët-Pastré, Harvard University Press, Cambridge, pp. 255-268.

Gates, H. (1996) China's Motor: A Thousand Years of Petty Capitalism, Cornell University Press, Ithaca.

Harding, S. (2000) The Book of Jerry Falwell: Fundamentalist Language and Politics, Princeton University Press, Princeton.

Herzfeld, M. (1997) Cultural Intimacy: Social Poetics in the Nation-State, Routledge, New York.

Hua, H. (2009) 'A Study of the Characteristics of Chinese Student Christians in Paris', Youth Studies, vol. 6, pp. 64-73.

Huang, C. J. (2009) Charisma and Compassion: Cheng Yen and the Buddhist Tzu Ch Movement, Harvard University Press, Cambridge.

Kipnis, A. (2004) 'Anthropology and the Theorisation of Citizenship', The Asia Pacific Journal of Anthropology, vol.5, no.3, pp. 257-78.

Lee, D. (2007) ‘China's Global Go-getters’, Los Angeles Times, March 12, p.A1.

Levitt, P. (2007) God Needs No Passport: Immigrants and the Changing American Religious Landscape, New Press, New York.

Ma Mung, E. (1998) 'Economic Arrangement and Spatial Resources: Elements of a Diaspora Economy', in. The Chinese Diaspora: Selected Essays, eds L.-c. Wang \& G. Wang, Times Academic Press, Singapore, pp. 131-49.

Min, P. G. (1992) 'The Structure and Social Functions of Korean Immigrant Churches in the United States’, International Migration Review, vol. 26, pp.1370-394.

Nagata, J. (2005) 'Christianity among Transnational Chinese: Religious versus (Sub)ethnic Affiliation', International Migration, vol. 43, no.3, pp. 99-130.

Nyíri, P. (2003) 'Moving Targets: Chinese Christian Proselytising Among Transnational Migrants from the People's Republic of China', European Journal of East Asian Studies, vol. 2, no. 2, pp. 263-301.

Oxfeld, E. (2010) Drink Water, but Remember the Source: Moral Discourse in a Chinese Village, University of California Press, Berkeley.

Robbins, J. (2001) 'God is Nothing But Talk: Modernity, Language, and Prayer in a Papua New Guinea Society', American Anthropologist, vol. 103, no. 4, pp. 901-912.

Taylor, P. (2006) 'Economy in Motion: Cham Muslim Traders in the Mekong Delta', The Asia Pacific Journal of Anthropology, vol. 7, no. 3, pp. 237-250. 
Wang, C, \& Béja, J. P. (1999) 'Wenzhou ren zai bali: yizhong dute de shehui rongru moshi' (The Wenzhounese in Paris: A Unique Model of Social Integration), Zhongguo shehui kexue, vol. 6, pp. 106-19.

Xiang, B. (2005) Transcending Boundaries, Trans. Jim Weldon, Brill, Leiden.

Yang, F. (1999) Chinese Christians in America, Pennsylvania State University Press, Temple.

Yang, M. H. (2000) 'Putting Global Capitalism in Its Place: Economic Hybridity, Bataille, and Ritual Expenditure', Current Anthropology, vol. 41, no 4, pp. 477-509.

Zhang, L. (2001) Strangers in the City: Reconfigurations of Space, Power, and Social Networks within China’s Floating Population, Stanford University Press, Stanford.

Zhou, M. (1992) Chinatown: The Socioeconomic Potential of an Urban Enclave, Temple University Press, Philadelphia. 